\title{
Biological Assessments on Bio-polymer Coated with Non-toxic Materials
}

\author{
Hong-Kyu Ahn, Sang-Hoon Lee, and In-Tae Lee
}

\begin{abstract}
When the ecological river restoration projects using the concrete material are performed, various biological problems can occur as a result of that water quality degradation due to strong alkali and heavy metal such as lead and chromium and exposure of aquatic organisms to toxic environments during long term. Thus, in this study, biological monitoring (biomass and community characteristics, etc.) and health evaluation were carried out by attached algae using application of vegetation-based polyurethane as non-toxic material for the ecological restoration of rivers. Experiments are evaluated ecological property for non-toxic materials using concrete bricks, coated plant-based polyurethane concrete bricks and natural stone. In addition, the target river was investigated by basic biological research.
\end{abstract}

Index Terms-Non-toxic material, plant-based polyurethane, ecological health, periphyton, monitoring.

\section{INTRODUCTION}

Concrete materials have been much used in conventional stream development and repair projects for water use and flood control. The examples of the use of concrete materials are existing weirs in local streams, river bed protection, and drop structures. However, excessive use of concrete materials can have adverse effects on water quality and ecological system disturbance due to strong alkali, heavy metals and damages to stream sceneries. In particular, its functionality can be lost due to climate changes such as flood due to heavy rain or drought [1]. Therefore, it is necessary to require physical, chemical, and biological monitoring verification to develop a construction method technology utilizing non-toxic materials that are healthy for aquatic ecosystems in streams and safe hydrologically in local ecological stream restoration projects [2]. For biological monitoring, periphyton has been utilized as the most appropriate role in determination of pollutant by absorbing aquatic nutrients directly into cells as a producer in the food chain [3].

In this study, when applying a construction method and technology of integrated river bed protection utilizing

Manuscript received April 17, 2017; revised September 1, 2017. We hereby express our appreciation as this study was conducted by the research funding (12 INNOTECH C02) of the Water Resource Management Research Project by the Ministry of Land, Infrastructure and Transport.

Hong-Kyu Ahn and Sang-Hoon Lee are with the Hydro Science and Engineering Research Institute, Korea Institute of Civil Engineering and Building Technology, Goyang-si, 411-712, South Korea (e-mail: ahnhk@kict.re.kr).

In-Tae Lee is with the Research Institute for Coastal Environment and Fishery-policy, Industrial-Education Cooperation B/D Chonnam National University, Gwangiu, 500-757, South Korea. non-toxic material (plant-based polyurethane) already developed in Korea for the first time, the stability of biological monitoring result was verified according to the pre-basic study on periphyton, which is a basic unit of organisms within the water system and ecological health assessment due to the application of substrates.

\section{MAterials AND Methods}

\section{A. Riverbed and Vegetation Characteristics in the Study} Area

For the study area on periphyton, three sites at upstream, mid-stream, and downstream were selected around the pilot regions of riverbed maintenance in the Daecheongcheon stream of Gimhae City (Table I, II) [4]. The characteristics of the stream in the study area were as follows: the upstream was composed of $20 \%$ of riverbed sand and $80 \%$ of bedrock and stone, and its vegetation was mostly characterized by phragmites spp. vegetation. The midstream was made of $70 \%$ of riverbed sand and $30 \%$ of gravel, and its vegetation was characterized by herbaceous vegetation distribution. The downstream was composed of $20 \%$ of riverbed sand and $20 \%$ of gravel, and its vegetation was characterized by $50 \%$ of woody plant vegetation.

\section{B. Sampling Method}

\section{1) General (natural stones) sampling}

The substrate to collect periphyton was immersed at a water depth of $20 \mathrm{~cm}$ or lower for at least one week and a natural stone where the upper part was flat and horizontal with the flow was selected. A $5 \times 5 \mathrm{~cm}\left(25 \mathrm{~cm}^{2}\right)$ rubber plate was softly placed on the upper part of the substrate and a force was applied on the plate (Fig. 1,2). Then, the substrate was cleansed to collect periphyton using the stream water and iron brush. After this, the rubber plates and cleansed substrates were moved to vat where the entry was wide to collect a required amount.

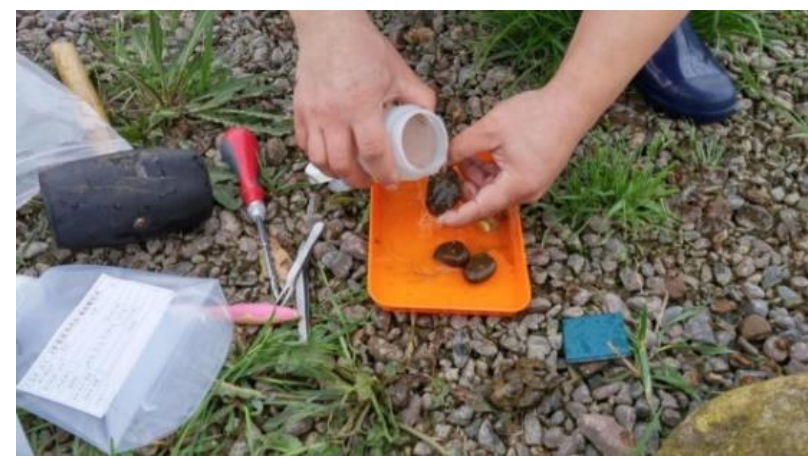

Fig. 1. Sampling method of periphyton from natural stones 


\section{2) Sampling from the artificial substrate}

In order to evaluate the substrate characteristics about the inhabitation of periphyton, bio-polymer artificial substrates coated with plant-based polyurethane and attachment substrates (bricks) without coating as control group were installed at the riverbed maintenance pilot section. The artificial substrates were supplied from the SBB (Co. Ltd.) and a size of each substrate was a $10 \times 25 \times 5 \mathrm{~cm}$ brick. Sampling from each substrate was done by placing the upper surface $5 \times 5 \mathrm{~cm}\left(25 \mathrm{~cm}^{2}\right)$ where the sunlight was contacted on the rubber plate and other surfaces were cleansed with a brush so that sampling was collected only from the surface shaded by the rubber plate (Fig. 3).

\section{Analysis on Biomass of Periphyton}

The collected samples were used to measure analysis on community of periphyton, chlorophyll (Chl-a) concentration, organic matter (ash free dry matter (AFDM). Chl-a was extracted for one day at dark condition of $4^{\circ} \mathrm{C}$ using $90 \%$ acetone after a certain amount of the sample was filtered with GF/C (Whatman Inc., England) and then centrifugation (MF80 Hanil Science Inc., Korea) was done to measure the absorbance of the supernatant (Spectrophotometer, SP-2700i Youngwoo Inc., Korea). The organic matter was calculated by using a weight difference between measured weight after filtering a certain amount of the collected periphyton using $\mathrm{GF} / \mathrm{C}$ and drying them at $105^{\circ} \mathrm{C}$ and a weight after burning them for one hour at $550^{\circ} \mathrm{C}$ crucible [5].
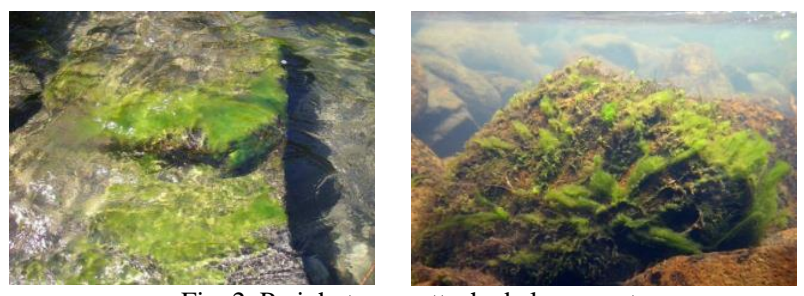

Fig. 2. Periphyton as attached algae on stone.

TABLE I: VIEWS OF EXPERIMENTS SITE

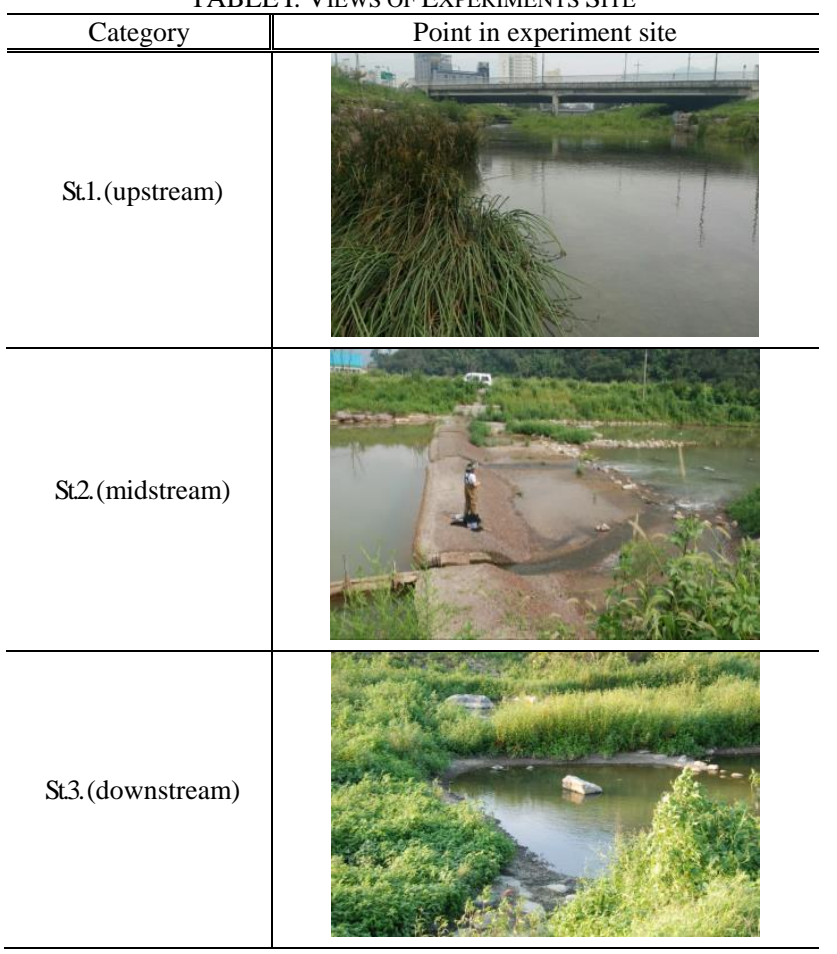

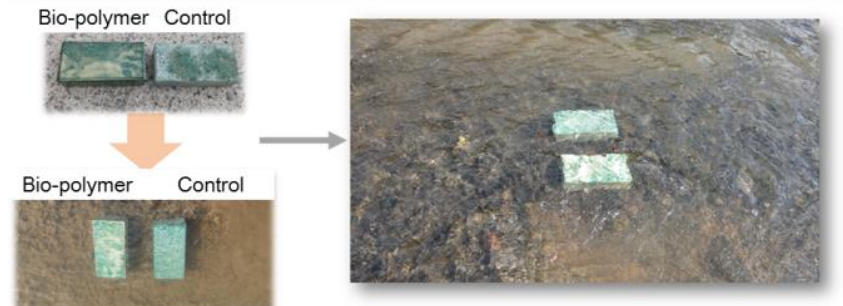

Fig. 3. Installation of the artificial substrate for periphyton sampling.

\section{Analysis on Periphyton}

The samples collected for community analysis on periphyton was fixed with Lugol liquid immediately after collection and dried using acid treatment via $\mathrm{KMnO}_{4}$ catalyst thereby fabricating a specimen for microscope observation using a mounting agent. The identification of the periphyton was conducted with permanent specimens at 400-1000 times magnification using an optical microscope (Nikon E600, Japan) [6]. A relative frequency of appearance species identified at each specimen was acquired to calculate the number of population of periphyton and at least 500 or more lived diatoms containing protoplast were counted from the natural sample without acid treatment. The cell density of the appearance species was calculated by multiplying the total population obtained in the above by the relative frequency. The dominant specifies and index of dominance were calculated based on the appearance species number of periphyton by site and cell density in order to identify the characteristics of the community of periphyton [7], [8].

\section{RESUlT AND DisCUSSION}

\section{A. Biomass of the Periphyton}

The measurement results on three sites upstream (St 1), midstream (St 2), and downstream (St 3) in the Daecheongcheon stream showed that an overall range of AFDM of periphyton was $0.35-1.20 \mathrm{mg} / \mathrm{cm}^{2}$, resulting in $0.78 \mathrm{mg} / \mathrm{cm}^{2}$ on average. The AFDMs for St 1, 2, and 3 were $0.35-0.64 \mathrm{mg} / \mathrm{cm}^{2}, 0.99-1.20 \mathrm{mg} / \mathrm{cm}^{2}$, and $0.41-1.17$ $\mathrm{mg} / \mathrm{cm}^{2}$. A mean AFDM at St 2 in the riverbed maintenance pilot section was 1.07 , which was relatively higher than other sites. The result of Chlorophyll-a was $0.47-2.62 \mu \mathrm{g} / \mathrm{cm}^{2}$, resulting in $1.58 \mu \mathrm{g} / \mathrm{cm}^{2}$ on average. The Chlorophyll-a for St 1,2 , and 3 were $0.47-1.64 \mu \mathrm{g} / \mathrm{cm}^{2}, 1.89-2.62 \mu \mathrm{g} / \mathrm{cm}^{2}$, and $1.12-1.78 \mu \mathrm{g} / \mathrm{cm}^{2}$ (Table III).

A mean value of Chlorophyll-a at site 2 in Daecheongcheon was 2.18, which was about $27.5 \%$ higher than total site mean, which was higher than those in the other two sites. The result of biomass of periphyton at each site in Daecheongcheon showed that site 2 biomass (AFDM, Chl-a) was relatively higher than the other two sites. This was because sites 1 and 3 had higher turbidity due to the inflow of organic matters from the surrounding areas and rainfalls whereas site 2 had an inflow of stream water from the nearby weir constructed at the upstream, which made faster flow and lower turbidity (diatoms) than other two sites. The growth inhibition or promotion of periphyton such as diatoms has 
been known to be affected by a flow rate, turbidity, and DO in streams [9], [10].

TABLE II: COORDINATES OF THE PERIPHYTON SAMPLE COLLECTION SITES AND FRONT VIEWS

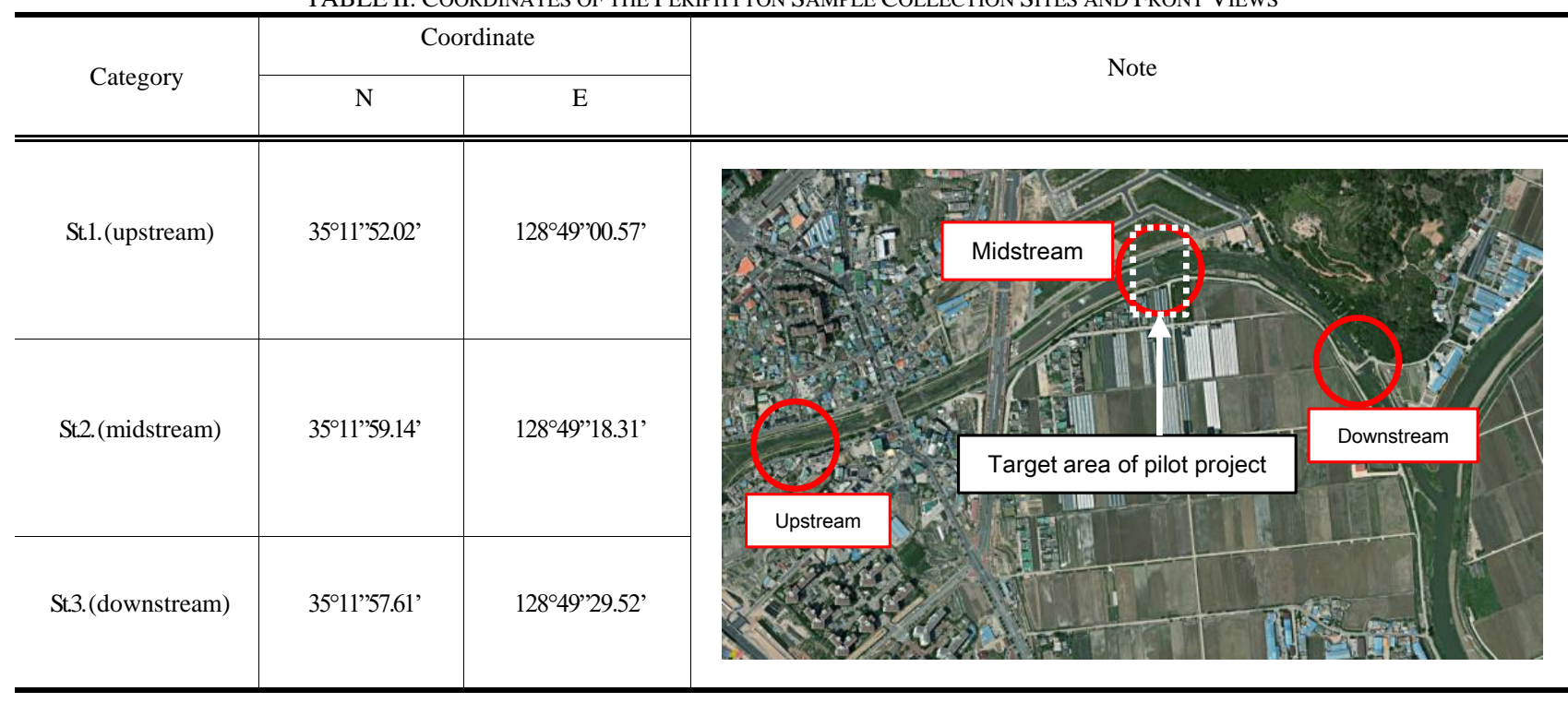

TABLE III: BIOMASS AT EACH SITE IN DAECHEONGCHEON

\begin{tabular}{|c|c|c|c|c|c|c|c|c|c|}
\hline \multirow{2}{*}{ Item } & \multicolumn{2}{|c|}{$1^{\text {st }}$ sampling } & \multicolumn{2}{|c|}{$2^{\text {nd }}$ sampling } & \multicolumn{3}{|c|}{$3^{\text {rd }}$ sampling } \\
\cline { 2 - 9 } & St 1 & St 2 & St 3 & St 1 & St 2 & St 3 & St 1 & St 2 & St 3 \\
\hline $\begin{array}{c}\text { Chl-a } \\
\left(\mu \mathrm{g} / \mathrm{cm}^{2}\right)\end{array}$ & 1.45 & 2.62 & 1.78 & 0.47 & 1.89 & 1.12 & 1.64 & 2.03 & 1.26 \\
\hline $\begin{array}{c}\text { AFDM } \\
\left(\mathrm{mg} / \mathrm{cm}^{2}\right)\end{array}$ & 0.35 & 1.20 & 1.17 & 0.40 & 1.01 & 0.87 & 0.64 & 0.99 & 0.41 \\
\hline
\end{tabular}

\section{B. Community Characteristic of Periphyton}

The study result on the community of periphyton at three sites in Daecheongcheon revealed that appearances of periphyton were 117 species in total ( 2 orders, 3 sub-orders, 10 families 20 genus, 89 species, and 28 mutinies). Among them, 30 species $(25.64 \%)$ of Saproxenic taxa appeared including Cymbella minuta of Cymbella and Cocconeis placentula var. lineata of Cocconeis and 17 species of Saprophilic taxa $(14.52 \%)$ appeared including Nitzschia palea of Nilzschia and Cyclotella meneghiniana of Cyclotella. A relatively less number of species in periphyton appeared in Site 2 of the riverbed protection pilot section whereas an appearance rate of Saproxenic taxa was 36\%, which was relatively higher than other two sites (21-32\%), showing a better habitation environment of periphyton. Furthermore, a density of periphyton was gradually decreased from upstream to downstream and a difference in the number of population and appearance species of periphyton was affected by the turbid water and a level of turbidity more than riverbed conditions (Table IV).

TABLE IV: APPEARANCE SPECIES NUMBER AND POPULATION OF PERIPHYTON BY SiTE IN THE WATER SYSTEM OF DAECHEONGCHEON

\begin{tabular}{|c|c|c|c|c|c|c|c|}
\hline \multirow[t]{2}{*}{ Site } & \multicolumn{4}{|c|}{ Appearance species number (species) } & \multicolumn{3}{|c|}{ Density $\left(\right.$ cells $\left./ \mathrm{cm}^{2}\right)$} \\
\hline & $\begin{array}{c}\text { Total species } \\
\text { number }\end{array}$ & Average & Maximum & Minimum & Average & Maximum & Minimum \\
\hline Site 1 & 58 & 23 & $\begin{array}{c}24 \\
\text { (First and Third) }\end{array}$ & $\begin{array}{c}22 \\
\text { (Second) }\end{array}$ & 310,697 & $\begin{array}{l}401,200 \\
\text { (Third) }\end{array}$ & $\begin{array}{l}248,140 \\
\text { (First) }\end{array}$ \\
\hline Site 2 & 53 & 21 & $\begin{array}{c}26 \\
\text { (Second) }\end{array}$ & $\begin{array}{c}17 \\
\text { (Third) }\end{array}$ & 266,820 & $\begin{array}{l}364,550 \\
\text { (Second) }\end{array}$ & $\begin{array}{l}191,960 \\
\text { (Third) }\end{array}$ \\
\hline Site 3 & 56 & 22 & $\begin{array}{c}23 \\
\text { (First and Second) }\end{array}$ & $\begin{array}{c}20 \\
\text { (Third) }\end{array}$ & 237,507 & $\begin{array}{c}289,620 \\
\text { (First) }\end{array}$ & $\begin{array}{l}165,650 \\
\text { (Third) }\end{array}$ \\
\hline
\end{tabular}

\section{Biomass and Community Characteristics of Periphyton by Substrate Type}

The biomass of periphyton with regard to three types of substrates was analyzed to evaluate substrate specificity of periphyton at the pilot section. The AFDM of periphyton was as follows: natural substrate $0.17 \mathrm{mg} / \mathrm{cm}^{2}$, bio-polymer 0.14 $\mathrm{mg} / \mathrm{cm}^{2}$, and non-coating substrate $0.64 \mathrm{mg} / \mathrm{cm}^{2}$, indicating that natural substrate and bio-polymer substrate showed a similar tendency (Fig. 4). A Chlorophyll concentration showed that natural substrate $0.68 \mu \mathrm{g} / \mathrm{cm}^{2}$, bio-polymer 0.75 $\mu \mathrm{g} / \mathrm{cm}^{2}$, and non-coating substrate $1.99 \mu \mathrm{g} / \mathrm{cm}^{2}$, indicating no significant difference between natural and bio-polymer substrates. For non-coating substrates, its surface roughness was different from the other two substrates, which was why the attachment of benthic algae was easier. The characteristics of periphyton according to substrates according to natural, non-coating, and bio-polymer substrates showed appearances of 19 species $(154,420$ cells $\left./ \mathrm{cm}^{2}\right) 19$ species $\left(362,350\right.$ cells $\left./ \mathrm{cm}^{2}\right)$, and 22 species $\left(274,230\right.$ cells $\left./ \mathrm{cm}^{2}\right)$. Among them, Saprophilic taxa and Saproxenic taxa were 5/4 species, 8/5 species, and 4/9 species. An appearance rate of Saproxenic taxa among the taxon of periphyton attached to the bio-polymer substrate 
was $41 \%$. This result indicated that the bio-polymer substrate played a role in providing a stable habitat than the other two substrates.
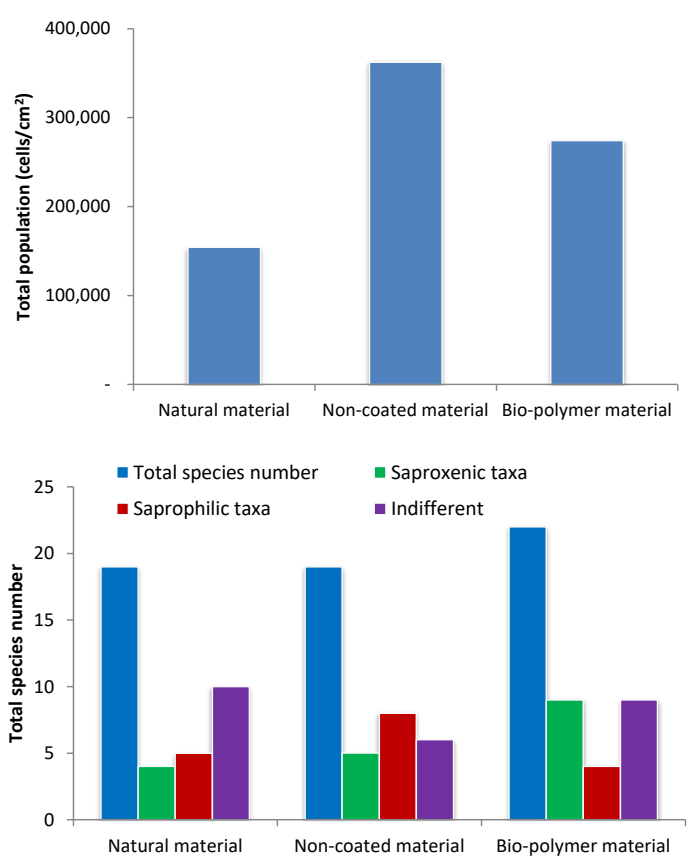

Fig. 4. Biomass population and species of periphyton by substrate type.

\section{CONCLUSION}

In this study, biological health assessment on plant-based polyurethane bio-polymer substrate, which was pre-developed main raw material used for riverbed protection, was performed in the hydro-ecological system. The study result showed that 1) bio-polymer substrate had more appearance species of periphyton than natural and non-coating substrates and 2) bio-polymer substrate had higher species of Saproxenic taxa that were inhabited in relatively clean water environments thereby providing better health of hydro-ecological system along with more diverse species. Thus, the future development of various construction methods utilizing plant-based polyurethane can be applied for not only hydrological issues in streams but also sound circulation in the ecosystem.

\section{ACKNOWLEDGMENT}

We hereby express our appreciation as this study was conducted by the research funding (12 INNOTECH C02) of the Water Resource Management Research Project by the Ministry of Land, Infrastructure and Transport. And special thanks to SBB Co. Ltd. and BASF Ltd. for research support.

\section{REFERENCES}

[1] D. W. Fowler, "Polymers in concrete: A vision for the 21st century," Cement and Concrete Composites, vol. 21, pp. 449-452, 1999.

[2] S. Sato, T. Kuwabara, H. Ashida, and T. Nonaka, "Studies on dissolution characteristic of heavy metals from cement hydrates and its safety evaluation," in Proc. Annual Conference in Japan Concrete Institute, vol. 30, pp. 343-348, 2008.

[3] M.-K. Ji et al., "Biodegradation of bisphenol A by the freshwater microalgae Chlamydomonas mexicana and Chlorella vulgaris," Ecological Engineering, vol. 73, pp. 260-269, 2014.

[4] H.-K. Ahn, S.-H. Lee, and M.-K. Ji, "Development of ecological scour protection technique with non-toxic materials and examination of field application," International Journal of Environmental Science and Development, vol. 8, no. 3, p. 164, 2017.

[5] APHA, "Methods for biomass production," Standard Methods for the Examination of Water and Wastewater, American Public Health Association, Baltimore MD, 1998.

[6] J. Schwoerbel, Methods of Hydrobiology: (Freshwater Biology), Elsevier, 2016.

[7] C. Loehle, "Relative frequency function models for species distribution modeling," Ecography, vol. 35, no. 6, pp. 487-498, 2012.

[8] J. M. Andrus et al., "Spatial and temporal variation of algal assemblages in six Midwest agricultural streams having varying levels of atrazine and other physicochemical attributes," Science of the Total Environment, vol. 505, pp. 65-89, 2015.

[9] J. Shao et al., "Potential for control of harmful cyanobacterial blooms using biologically derived substances: Problems and prospects," Journal of Environmental Management, vol. 125, pp. 149-155, 2013.

[10] F. Larras et al., "Using bioassays and species sensitivity distributions to assess herbicide toxicity towards benthic diatoms," PloS One, vol. 7, no. 8, p. e44458, 2012.

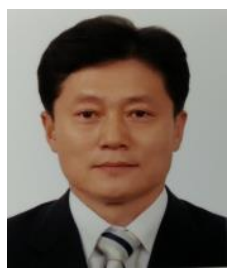

Hong Kyu Ahn was born on April 3, 1964. His major field of study: eco-technology, soil conservation engineering. He got the doctor's degree in soil conservation engineering at University of Tsukuba (Japan), Agriculture \& Forestry Engineering Research Department.

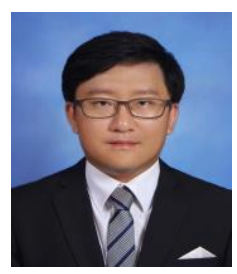

Sang-Hoon Lee was born on November 7, 1982. His major field of study: environmental engineering. He got the doctor's degree in environmental engineering at Yonsei University (Korea). His representative research achievements: "Perchlorate reduction from a highly concentrated aqueous solution by bacterium Rhodococcus sp. YSPW03," Environmental Science and Pollution Research, 2015.

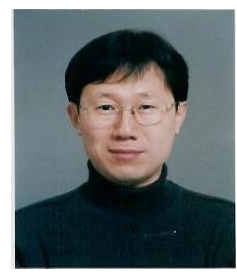

In Tae Lee was born on January 22, 1963. His major field of study: marine geology, marine policy. He got the doctor's degree in geology at University of Tsukuba (Japan), Institute of Geoscience, University of Tsukuba. His main achievements "Bottom current deposits in the miocene-pliocene misaki formation, Izu Forearc area, Japan," The Island Arc, vol. 7, pp. 315-329. 